\title{
Environmental and health risk assessment of particulate matter associated with sporting activities in Yenagoa metropolis, Nigeria
}

\author{
Tariwari C N Angaye ${ }^{1 *}$, Godbless N Oyinke ${ }^{2}$ and Odangowei I Ogidi ${ }^{3}$ \\ 1I1Department of Biological Science, Faculty of Science, Niger Delta University, Nigeria \\ ${ }^{2}$ Department of Family Medicine, Niger Delta University Teaching Hospital, Nigeria \\ ${ }^{3}$ Department of Science Laboratory Technology, Federal Polytechnic of Oil \& Gas Ekowe, Nigeria
}

\begin{abstract}
Over the decades there have been problems associated with Particulate Matter (PM) arising from anthropogenic activities. Evaluation and health risk assessment of particulate matter associated with football field was carried out in Yenagoa Metropolis Nigeria. Digital portable AEROCET 513 (Metone instrument) Particulate matter meter was used for evaluation of PM in 5 locations. Results showed that levels of particulate matter for; PM1.0 (13.73-20.18 $\left.\mu \mathrm{g} / \mathrm{m}^{3}\right), \mathrm{PM} 2.5(19.11-28.83$ $\left.\mu \mathrm{g} / \mathrm{m}^{3}\right)$, PM4.0 $\left(24.73-44.63 \mu \mathrm{g} / \mathrm{m}^{3}\right)$, PM7.0 (41.07-67.04 $\left.\mu \mathrm{g} / \mathrm{m}^{3}\right)$, and PM10 ranging from $65.48-90.82 \mu \mathrm{g} / \mathrm{m}^{3}$. In addition, value of the control station was lowest amongst all recorded values of particulate matter $(\mathrm{p}<0.05)$. Based on Air Quality Index football field were predominantly rated as either; unhealthy or very unhealthy, with only few cases of unsafe for sensitive group. This investigation therefore concludes that the emission of particulates matter of the football field are reflection of vehicular emissions and agitated dust particles. Hence mitigable measure must be applied without much ado, in order to ameliorate chronic daily exposure to PM.
\end{abstract}

\section{Introduction}

Air pollution is the release of substances that are capable of infringing on ambient quality of the air [1]. The adverse effects of the pollutant might be acute or chronic, depending on the on the specie, concentration, kind and properties of the pollutant [2]. Pollution is also seen as a process that involves the infringement of the environment by substances capable of inducing adverse effect to the environment including other forms of biota [3-5]. Air pollutants includes organic or inorganic agents such as particulate matter, microbes, heavy metals, metabolites etc. [1]. Statistically, on annual basis there are over two million global cases of mortality linked to air pollution, with adverse effects on the respiratory system [6]. Furthermore, most cases were due to emission of fine particulate matter $[6,7]$.

Particulate matter is a compounding aggregation of solid or liquid particulates that is suspended or persistent in the air over a period of time [8]. Particulate matter varies in sizes, not withstanding, they are broadly characterized as fine $(\leq 2.5 \mu \mathrm{m})$, and coarse particulate matter ranging from $>2.5 \mu \mathrm{m}$ [9]. Finer particulate matter poses more health problems due to their ability to penetrate the lung as opposed to coarse and larger particles [10]. For instance, PM1.0 which is a fine particulate matter is rates as the most lethal, with cases of infant mortality and heart problems [9].

As established in literature by Araújo, et al., for the determination of the extent of pollution in any country it is habitual to establish references backgrounds. These air quality background will be become standards that describe the threshold concentration of air pollutant, whose exceedances can affect bio diversities. Currently, there are no comprehensive air quality backgrounds for most developing countries as most researchers often depends on guideline from the World Health Organisation [11]. Yenagoa metropolis is the capital city of Bayeslsa state, and with dusty football field having poor vegetation cover, in addition to their proximity to traffic zone. Engagement of this field for sporting activities might induce exposure to suspended particulate matter. As such this investigation have become necessary.

\section{Materials and methods}

\section{Study area}

The study area (Yenagoa Metropolis), is the State Capital Territory of Bayelsa State. It is a wet land located on the southernmost part of Nigeria. It has a deltaic landmass and characterized by shallow aquifer with several networks of creek and creeklets. It has two prevailing seasons, which are dry and wet season. During the dry season it is usually windy and dusty with no precipitation, while in wet season there is high level of precipitation [1].

\section{Sampling}

The sampling of particulate matter was carried out in 5 location, including the control station. Portable Metone AEROCET 531 Particulate matter meter was used during the sampling. During sampling, the meter was power on with the probe facing the windward direction. The meter runs for approximately 1 minute, after which the result was ready for reading on the screen. Depending on the

${ }^{*}$ Correspondence to: Tariwari C N Angaye, Department of Biological Science, Faculty of Science, Niger Delta University, Nigeria, E-mail: maktarry@yahoo.com

Key words: particulate matter, health risk, Yenagoa, chronic exposure

Received: July 17, 2019; Accepted: December 02, 2019; Published: December 06,2019 
sizes of the particulate matter, the meter speciates particulates based on their diameter per cubic meter $\left(\mu \mathrm{g} / \mathrm{m}^{3}\right)$. As such particulates are characterized as PM1.0, PM2.5, PM4.0, PM7.0, PM10 and Total Suspended Particulate (TSP).

\section{Air quality index (AQI)}

The Air Quality Index (AQI) is a model scheme developed to quantify the health risk for air quality in the atmosphere, based on individual air quality and a certain reference of background value. This may include; geometric mean, control or the regulatory limit value of the geographical area [12]. The individual concentrations of particulate matter is calculated using the AQI scheme of Lingan, et al., with slight modification. The value of the control station was used as the reference background (Table 1).

$$
A Q I=100 \frac{V}{V S}
$$

Where $\mathrm{V}$ is individual concentration of particulate matter

VS is value of the control station

\section{Statistical analysis}

All results are expressed as Mean \pm Standard Deviation. Analysis of variance was carried out. The applied Post-Hoc was used to establish differences was Duncan's multiple range test $(\mathrm{P}<0.05)$. The Mean data were used to plot charts using Microsoft excel (2013 version).

\section{Results and discussion}

Result on the spatial levels of particulate matter associated with the football field is presented in Figure 1. Based on spatial distribution of the football field, higher levels of PM1.0 particulate matter ranging from

Table 1. Scheme for assessment of Air Quality Index

\begin{tabular}{|c|c|c|}
\hline Index Categories & Index Magnitude & Impact Classification \\
\hline A & $0-50$ & Safe \\
\hline B & $51-100$ & Moderate \\
\hline C & $101-150$ & Unsafe for sensitive group \\
\hline D & $150-200$ & Unhealthy \\
\hline E & $201-300$ & Very Unhealthy \\
\hline F & $>300$ & Hazardous \\
\hline
\end{tabular}

Table 2. Health risk assessment of air quality in the study area

\begin{tabular}{|c|c|c|c|c|c|}
\hline Locations & PM1.0 & PM2.5 & PM4.0 & PM7.0 & PM10 \\
\hline L1 & 133.70 & 144.40 & 127.10 & 122.90 & 132.20 \\
\hline L2 & 193.88 & 195.40 & 204.43 & 166.20 & 183.30 \\
\hline L3 & 177.23 & 180.60 & 169.20 & 153.32 & 150.10 \\
\hline L4 & 234.60 & 224.48 & 227.40 & 200.70 & 171.10 \\
\hline
\end{tabular}

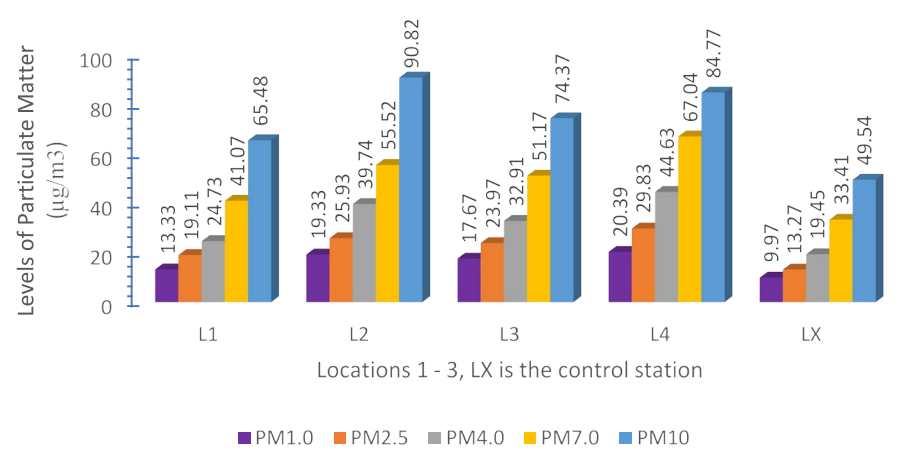

Figure 1. Levels of particulate matter in the study area
13.33-20.39 $\mu \mathrm{g} / \mathrm{m}^{3}$ was reported, compared to the control station that had the lower value $\left(9.97 \mu \mathrm{g} / \mathrm{m}^{3}\right)$. However, the highest level of PM1.0 particulate matter was reported in station L4 (Figure 1). On the other hand, the lowest value was reported in station L1. Moreover, based on the model for health risk of PM1.0 particulate matter associated with the football field indicated that it was unsafe for sensitive group in station L1. An unhealthy condition was indicated in stations; L2 and L3, while station L4 indicated a very unhealthy condition (Table 2).

The level of PM2.5 particulate matter associated with the football field ranged from $19.11-29.83 \mu \mathrm{g} / \mathrm{m}^{3}$. The highest value was reported in station L4, while the lowest value was reported in station L1 (Figure 1). In addition, the control station $\left(13.27 \mu \mathrm{g} / \mathrm{m}^{3}\right)$ indicated the lowest level of PM2.5 particulate matter (Figure 1). Based on the model for health risk assessment, the levels of PM2.5 particulate matter station L1 was unsafe for sensitive group, stations L2 and L3 were unhealthy, while station L4 was very unhealthy (Table 2).

Based on spatial distribution, the levels of PM4.0 particulate matter in the football field ranges from $24.73-44.63 \mu \mathrm{g} / \mathrm{m}^{3}$, with a much lower value in the control station $\left(19.45 \mu \mathrm{g} / \mathrm{m}^{3}\right)$ as presented in Figure 1. In addition, the highest level of PM4.0 particulate matter was reported in station L4, while the lowest value was reported in station L1 (Figure 1). Based on health risk assessment, PM4.0 particulate matter it was unsafe for sensitive group in station L1. Meanwhile it was unhealthy in station L3 (Table 2). Stations L2 and L4 indicated a very unhealthy condition (Table 2).

As presented in Figure 1, the spatial levels of PM7.0 particulate matter ranges from $41.07-67.04 \mu \mathrm{g} / \mathrm{m}^{3}$, with a lower value in the control station $\left(33.41 \mu \mathrm{g} / \mathrm{m}^{3}\right)$. Meanwhile, the highest and lowest values of PM7.0 particulate matter was reported in stations L4 and L1 respectively. Based on the modelling for health risk assessment of the football field, station L4 was very unhealthy, station L1 was unsafe for sensitive group, while stations L2 and L3 was unhealthy (Table 2). The spatial level if PM10 particulate matter associated with the football field ranges from $65.48-90.82 \mu \mathrm{g} / \mathrm{m}^{3}$ (Figure 1). Meanwhile, the highest level of PM10 particulate matter was indicated in station L2, while the lowest value was indicated in station L1 (Figure 1). Notwithstanding, based on model for health risk assessment of the football field, stations L1and L3 were unhealthy for sensitive group, while L2 and L4 were rated to be unhealthy.

Result of this study is comparable to previous study of Angaye, et al. [1], for temporal speciation of particulate matter (dry and wet season respectively), associated with dumpsites for; PM1 (17.04-32.81 and $\left.14.03-19.03 \mu \mathrm{g} / \mathrm{m}^{3}\right)$, PM2.5 (23.11-44.87 and $20.41-32.07 \mu \mathrm{g} / \mathrm{m}^{3}$ ), PM4 (32.03-62.80 and $\left.29.82-50.54 \mu \mathrm{g} / \mathrm{m}^{3}\right)$, PM7 (75.01-197.11 and $\left.45.17-71.27 \mu \mathrm{g} / \mathrm{m}^{3}\right)$, PM10 (109.40-305.10 and 56.53-93.07 $\left.\mu \mathrm{g} / \mathrm{m}^{3}\right)$, and Total Suspended Particulate (227.66-597.26 and 72.40-172.23 $\mu \mathrm{g} /$ $\mathrm{m}^{3}$ ). The result indicated that levels of particulate matter in dry season was significantly $(\mathrm{p}<0.05)$ higher compared to wet season.

As established in literature by several authors, ambient air quality in major cities across Nigeria's have been impaired by emission of Particulate Matter. Total Suspended Particulate ranging from 1033$40000 \mu \mathrm{g} / \mathrm{m}^{3}$ in industrial area of Lagos city [13]. In Maiduguri and Abuja PM10 ranging from 118.3-132.0 $\mu \mathrm{g} / \mathrm{m}^{3}$ was reported [14]. In some randomly selected Lagos levels of PM2.5 and PM10 were 27 and $69 \mu \mathrm{g} / \mathrm{m}^{3}$ respectively [15]. In Abuja and Aba the level of PM2.5 were $14 \mu \mathrm{g} / \mathrm{m}^{3}$ and $102 \mu \mathrm{g} / \mathrm{m}^{3}$ while PM10 level were reported as $38 \mu \mathrm{g} / \mathrm{m}^{3}$ and $553 \mu \mathrm{g} / \mathrm{m}^{3}$. 
The reports of Obioh, et al. [11] has revealed PM10 concentration of $38 \mu \mathrm{g} / \mathrm{m}^{3}$ in Abuja and $553 \mu \mathrm{g} / \mathrm{m}^{3}$ in Aba; and PM2.5 concentration varying between $14 \mu \mathrm{g} / \mathrm{m}^{3}$ in Abuja and $102 \mu \mathrm{g} / \mathrm{m}^{3}$ in Aba. Ideriah, et al. [16] have measured TSP concentration range of $19.0-1677.9 \mu \mathrm{g} /$ $\mathrm{m}^{3}$ in five communities in south eastern Nigeria. A study by Ohimain, et al. [17] at a palm oil processing industry in Elele, Rivers recorded the TSP values between 1634 and $7853 \mu \mathrm{g} / \mathrm{m}^{3}$. These reported PM values were greater than the USEPA (2008) daily and annual mean standards of 150 and $50 \mu \mathrm{g} / \mathrm{m}^{3}$, respectively. A study at a steel and iron industry in Lagos by Owoade, et al. [15] for PM10 and PM2.5 revealed concentration ranges of $86-8765 \mu \mathrm{g} / \mathrm{m}^{3}$ and $10-462 \mu \mathrm{g} / \mathrm{m}^{3}$, respectively. The unusually high concentrations of these PM size fractions may be harmful to the public, especially the residents living around the vicinity of the steelworks industry.

High level of particulate matter exceeding regulatory limits of the World Health Organisation $\left(90 \mu \mathrm{g} / \mathrm{m}^{3}\right)$ have been previously reported across major cities in Nigeria. For instance, the value of PM10 and Total Suspended Particulate (TSP), ranging from 118.3-132.0 and 1033 to $40000 \mu \mathrm{g} / \mathrm{m}^{3}$ have been reported [14]. As reported by several authors, health cases linked to exposure of particulate matter includes but not limited to; untimely death of persons who present cases of heart or lung infection, intensified asthma, heart attacks, asymmetrical heartbeat, deteriorated lung function, and amplified respiratory symptoms which includes; coughing, irritation of the airways, or difficulty breathing.

\section{Conclusion}

Evaluation and Health Risk Assessment of Particulate Matter around football field of Yenagoa Metropolis Nigeria was investigated. Model for Air Quality Index (AQI) was used to determine the health risk. Unfortunately, most of the all the football field had significant levels of particulate matter for PM1.0, PM2.5, PM4.0, PM7.0 and PM10. Based on AQI modelling, none of the playground relatively. Health risk indications were; unsafe for sensitive group, unhealthy and very unhealthy. The levels of particulate matter emission is a reflection of anthropogenic activities from agitated dust particles from poor vegetation cover of the field, we also recommend the monitoring of air quality in public places in order to avert chronic intake of particulate matter.

\section{References}

1. Angaye TCN, Abowei JFN (2018) Evaluation of suspended particulate matter (SPM) around municipal solid waste dumpsites in Yenagoa metropolis, Nigeria. MOJ Toxicol 4: 54-57.

2. Daly A, Zannetti P (2007) An introduction to air pollution - definitions, classifications, and history. Chapter 1 of Ambient Air Pollution; Zannetti P, Al-Ajmi D, Al-Rashied S, Eds.; The Arab School for Science and Technology (ASST), The Enviro Comp Institute: Freemont, CA, USA.

3. Kinney PL (2008) Climate change, air quality, and human health. Am J Prev Med 35 459-467.

4. Brauer M, Amann M, Burnett RT, Cohen A, Dentener F, et al. (2012) Exposure assessment for estimation of the global burden of disease attributable to outdoor air pollution. Environ Sci Technol 46: 652-660.

5. Kim K-H, Jahan SA, Kabir E (2013) A review on human health perspective of air pollution with respect to allergies and asthma. Environ Int 59: 41-52.

6. Shah ASV, Langrish JP, Nair H, McAllister DA, Hunter AL, et al. (2013) Globa association of air pollution and heart failure: A systematic review and meta-analysis. The Lancet 382: 1039-1048.

7. Chuang K-J, Yan Y-H, Chiu S-Y, Cheng TJ (2011) Long-termair pollution exposure and risk factors for cardiovascular diseases among the elderly in Taiwan. Occup Environ Med 68: 64-68.

8. World Health Organization \& UNAIDS (2006) Air quality guidelines: global update 2005. World Health Organization.

9. US-EPA (2010) Health Particulate Matter, Air and Radiation.

10. Brown JS, Gordons T, Price O, Asghrian B (2013) Thoracic and reparable particulate definition for human health risk assessment. Part Fibre Toxicol 10: 12.

11. Obioh IB, Ezeh GC, Abiye OE, Alpha A, Ojo EO, et al. (2013) Atmospheric particulate matter in Nigerian megacities. Toxicol Environ Chem 95: 379-385.

12. Bhutiani R, Kulkarni DB, Khanna DR, Gautam A (2017) Geochemical distribution and environmental risk assessment of heavy metals in groundwater of an industrial area and its surroundings, Haridwar, India. Energy, Ecology and Environment 2: 155-167.

13. Oluyemi EO, Asubiojo OI, Oluwole AF, Toussaint CJN (1994) Elemental concentrations and source identification of air particulate matter at a Nigerian site: A preliminary study. J Radioanal Nucl Chem 179: 187-194.

14. Taiwo AM, Arowolo TA, Abdullahi KI, Taiwo OT (2015) Particulate Matter Pollution in Nigeria: A review. Proceedings of the 14th International Conference on Environmental Science and Technology Rhodes, Greece.

15. Owoade OK, Fawole OG, Olise FS, Ogundele LT, Olaniyi HB, et al. (2013) Characterization and source identification of airborne particulate loadings at receptor site-classes of Lagos mega-city, Nigeria. J Air \& Waste Managt Assoc 63: 1026-1029.

16. Ideriah TJK, Braide SA, Fekarurhobo G, Oruambo I (2001) Determination of indoor and outdoor concentrations of suspended particulate matter in South eastern Nigeria Ghana J Sci 41: 23-27.

17. Ohimain E, Izah S, Abah S (2013) Air quality impacts of smallholder oil palm processing in Nigeria. J Environ Prot 4: 83-98.

Copyright: (C2019 Angaye TCN. This is an open-access article distributed under the terms of the Creative Commons Attribution License, which permits unrestricted use, distribution, and reproduction in any medium, provided the original author and source are credited. 